\title{
Implication of nitric oxide in the increased islet-cells vulnerability of adult progeny from protein-restricted mothers and its prevention by taurine
}

\author{
K Goosse, T Bouckenooghe, M Balteau, B Reusens and C Remacle \\ Laboratory of Cell Biology, Université Catholique de Louvain, Place Croix du Sud 5, 1348 Louvain-La-Neuve, Belgium \\ (Correspondence should be addressed to B Reusens; Email: brigitte.reusens@uclouvain.be)
}

\begin{abstract}
An increased vulnerability of adult $\beta$-cells seems to be programmed in early life as adult islets from the progeny of dams fed a low-protein diet exhibited an increased apoptotic rate after cytokine stimulation. This was prevented by maternal taurine supplementation. Here, we investigated the mechanisms implicated in such an increased vulnerability and how taurine exerts its protective role. Throughout gestation and lactation, Wistar rats were fed a $20 \%$ (control (C group)) or an isocaloric $8 \%$ protein diet (recovery ( $\mathrm{R}$ group)) supplemented or not with taurine (control+ taurine and recovery + taurine groups respectively). Offspring received a $20 \%$ protein diet after weaning. Islets from $3-$ month-old females were isolated and cultured for $48 \mathrm{~h}$ before being incubated with or without cytokines for $24 \mathrm{~h}$. In unstimulated islets, apoptotic rate and $\mathrm{NO}^{*}$ secretion were higher in R than in C. Both GADD153 mRNA and protein
\end{abstract}

were increased, whereas mRNA of mitochondrial gene ATPase 6 was downregulated in R group compared with C. In the RT group, taurine prevented apoptosis and restored a normal NO* production in GADD153 as well as ATPase6 mRNA expression. After cytokines-induction, apoptosis and $\mathrm{NO}^{*}$ secretion were still increased in $\mathrm{R}$ compared with $\mathrm{C}$ but both parameters were normalized in the RT group. In conclusion, a maternal low-protein diet programmes a different pattern of gene expression in islet-cells of adult progeny. Higher $\mathrm{NO}^{*}$ production by these islets could be an important factor in the subsequent cell death. The prevention of these events by maternal taurine supplementation emphasizes the importance of taurine during endocrine pancreas development.

Journal of Endocrinology (2009) 200, 177-187

\section{Introduction}

Much epidemiological data has emerged showing that an inappropriate maternal environment in which the foetus is developing generates a growth retardation that has been associated with the appearance of degenerative diseases including obesity, cardiovascular disease and diabetes in adulthood (Vanhala et al. 1998, Ravelli et al. 2005, Barker et al. 2007). This leads to the conclusion that adult diseases may originate during organ development and suggests that a programming of pathologies is possible. According to Hales \& Barker (2001), the most important cause of foetal growth retardation at the world scale is maternal malnutrition. For this reason, we developed an experimental rat model of foetal growth retardation induced by maternal low-protein diet during pregnancy. In this model, the development of the endocrine pancreas of the offspring was affected. $\beta$-cell proliferation, pancreatic insulin content and insulin secretion were decreased (Snoeck et al. 1990, Dahri et al. 1991), whereas islet cell apoptosis was increased in the presence or absence of nitric oxide donor or cytokines (Merezak et al.
2001). Maternal low-protein diet modified the amino acid profile in plasma (Reusens et al. 1995). Taurine, which is particularly important during embryological development (Sturman 1993), was found to be severely reduced in both mothers and their foetuses. When taurine was given to lowprotein fed mothers along gestation, most of the damages observed in the foetal islets were restored (Cherif et al. 1998, Boujendar et al. 2002, Merezak et al. 2001).

Long-term maternal malnutrition imprints islet behaviour, since, Merezak et al. (2004) demonstrated that in adulthood, islets of adult rats fed a protein restricted diet during early life developed a higher vulnerability towards cytokine-induced apoptosis than normally fed rats. Supplementation of malnourished mothers with taurine normalized apoptosis in these adult islets.

Signal transduction leading to cytokines-mediated $\beta$-cell apoptosis is achieved by modulation of genes expression including upregulation of Fas receptor and stimulation of inducible nitric oxide synthase (iNOS). Fas is a cell surface receptor belonging to the TNF receptor super family that triggers apoptosis via Fas-ligand recognition and subsequent 
caspases activation (Eizirik \& Mandrup-Poulsen 2001). In inflammatory conditions, $\mathrm{NO}^{\bullet}$ predominantly produced by iNOS reacts with superoxide anion $\left(\mathrm{O}_{2}^{-}\right)$to produce peroxinitrite $\left(\mathrm{ONOO}^{-}\right)$. This oxidant is more reactive than the parent molecules and generates several cellular dysfunctions including inhibition of haem containing enzymes, lipid peroxidation in membranes and lipoproteins, as well as induction of nuclear and mitochondrial DNA mutations (Eizirik \& Pavlovic 1997).

Impairment of ER homeostasis leads to unfolded and misfolded protein accumulation which threatens cell survival. When the threshold of cell death has not been reached, unfolded protein response (UPR) reduces general protein synthesis (Harding \& Ron 2002) and activates selective chaperones such as $\operatorname{IgG}$ heavy chain binding protein (BiP; Kozutsumi et al. 1988). During ER stress, calcium homeostasis is disrupted and the ion is released in the cytosol. In $\beta$-cells sarco-endoplasmic reticulum $\mathrm{Ca}^{2+}$-ATPase2b (SERCA2b) actively reloads calcium into the lumen of the ER (Arredouani et al. 2002). However, in severe ER stress, UPR activates the translation of transcription factor 'growth arrest and DNA damage inducible-protein 153 (GADD153)' which triggers apoptosis (Oyadomari \& Mori 2004). GADD153 is not restricted to ER stress pathways since redox stress (McCullough et al. 2001) and amino acid deprivation (Bruhat et al. 1997, Averous et al. 2004) induce the expression of this proapoptotic factor. Indeed, mitochondrial dysfunction caused by mitochondrial mutations has also been involved in GADD153 overexpression (Fujita et al. 2007). Mitochondria play a crucial role in the regulation of cell survival and death (Duchen 2004). Increasing evidence suggests that mitochondrial impairment intervenes in different pathologies including neurodegenerative disorders (Schapira 2006) and diabetes (Newsholme et al. 2007).

The aim of this study was to investigate the mechanisms implicated in the higher vulnerability of adult islets from early malnourished rats and to understand the role played by taurine in the protection of cytokine-induced islet cell apoptosis. We focused on several elements of ER and mitochondrial function to evaluate a possible influence of early low-protein diet and early taurine supplementation on islet cell death.

\section{Materials and methods}

\section{Animals}

Wistar male rats were caged overnight with females and copulation was verified next morning by the presence of spermatozoa in the female vagina. Pregnant rats were then divided into four groups depending upon the diet that was administered. A $20 \%$ protein diet was given to animals of the control group (C group), whereas rats of the recovery group were fed an isocaloric $8 \%$ protein diet ( $\mathrm{R}$ group) during gestation and lactation. To investigate the effect of taurine, some rats received a control or a low-protein diet supplemented with $2 \cdot 5 \% \mathrm{w} / \mathrm{v}$ taurine in the drinking water (control+taurine (CT group) or recovery + taurine (RT group)). After weaning (day 21), rats of each group received a $20 \%$ protein diet until adult age. Animals had free access to water and food during all the experiment. They were maintained at $25{ }^{\circ} \mathrm{C}$ with a $10 \mathrm{~h}: 14 \mathrm{~h}$ darkness: light cycle. Diets were purchased from Hope Farms (Woerden, Holland); the composition has been described previously (Bieswal et al. 2004). All procedures were carried out in accordance with 'Principles of laboratory animal care' (NIH publication no. 85-23, revised 1985) and with the approval of the animal ethics committee of the Universite catholique de Louvain.

\section{Cell culture and treatment}

For each islet isolation, two rats from the same mother were used. Then, islets from these two rats were pooled representing thus one independent experiment that was repeated five to eight times. Pancreatic islets were isolated from the 90-day-old offspring by collagenase digestion. Animals were killed and pancreases were perfused with $10 \mathrm{ml}$ of a $580 \mathrm{mg} / \mathrm{l}$ type XI collagenase $(1.38 \mathrm{U} / \mathrm{mg}$ specific activity, Sigma), diluted in HBSS containing DNase (200 mg/l, Roche). Glands were then removed, cleaned and minced. After sedimentation, the supernatant fluid was eliminated and the tissue was resuspended in an equal volume of a $116 \mathrm{mg} / \mathrm{l}$ type XI collagenase diluted in a DNAse/HBSS solution. Pancreas were shaken in a $37^{\circ} \mathrm{C}$ bath for $13 \mathrm{~min}$ to completely separate islets from exocrine tissue. Digestion was stopped by addition of ice cold HBSS. Islets were visualized by dithizone staining $(50 \mathrm{mg} / \mathrm{l}$, Sigma) and hand picked. Once washed in HBSS, islets were incubated in RPMI 1640 medium (Gibco) containing foetal bovine serum (5\% v/v) and antibiotics (3\% PenStrepFungizone solution (Cambrex, Charles City, IA, USA) and 0.5\% Gentamicin solution (Gibco)). After $24 \mathrm{~h}$ of culture, the islets were rinsed with serum-free DMEM/F12 medium (1:1 v/v; Gibco) containing $17 \cdot 51 \mathrm{mmol} / 1$ glucose and antibiotics. The following day, islets were exposed for $24 \mathrm{~h}$ to the same medium with or without $50 \mathrm{kU} / 1 \mathrm{IL} 1 \mathrm{~B}, 100 \mathrm{kU} / 1$ IFNG and $100 \mathrm{kU} / 1$ TNF (Gibco).

Islets were then picked and some were lysed in $500 \mu \mathrm{TRI}$ Reagent (Sigma) for mRNA isolation, while others were dissolved in $2 \% \mathrm{SDS} / 1 \%$ triton for protein extraction. A third part of islets was washed in PBS, permeabilized for $10 \mathrm{~min}$ in ethanol and frozen until apoptosis labelling. The culture media of islets exposed or not exposed to cytokines were also collected and stored at $-20^{\circ} \mathrm{C}$.

\section{Apoptosis labelling}

The level of apoptosis has been estimated by the TUNEL (TdT-mediated dUTP-X-nick end labelling) method. This technique is based on the DNA cleavage that occurs during the early stage of apoptosis. Fragmented DNA was detected by labelling the free $3^{\prime}-\mathrm{OH}$ termini with modified nucleotide (fluorescein-dUTP). The template polymerization was 
catalyzed by the enzyme terminal deoxynucleotidyl transferase $(\mathrm{TdT})$. We used the kit 'In Situ cell death detection kit, fluorescein' from Roche. Total islet nuclei were labelled with ethidium bromide (Sigma).

Stained probes were examined through a confocal laser scanning microscopy system (MRC-1024 u.v.; Bio-Rad) equipped with argon ion and krypton argon lasers. We have collected three optical sections of $10 \mu \mathrm{m}$ from each other per islet, and counted at least 10000 islet nuclei in each group. The total number of fluorescein-positive nuclei in the three sections was reported to the total number of ethidium positive nuclei and expressed as a percentage.

Nitric oxide $\left(\mathrm{NO}^{*}\right)$, monocyte chemoattractant protein-1 (MCP-1) and interferon- $\gamma$ inducible protein-10 (IP-10) measurements. The concentration of $\mathrm{NO}^{*}$ released in the culture medium was determined by analyzing a stable product of NO oxidation, the nitrite. In acidic conditions, nitrite reacts with 2, 3-diaminonaphtalene (Molecular Probes, Eugene, OR, USA) to form 3-diaminonaphtalene, the 1-(H)-naphthotriazole. To estimate the total quantity of NO secreted, nitrate was reduced to nitrite with a nitrate reductase from Aspergillus species (Sigma). 1-(H)-naphthotriazole was excited at $365 \mathrm{~nm}$ and measured at $460 \mathrm{~nm}$ (Fluoroskan Ascent Labsystems, Vantaa, Finland).

Commercially available ELISAs were used to quantify the secretion of both chemokines MCP-1 and IP-10. Samples were assayed for MCP-1 (BioSource International Inc., Camarillo, CA, USA) and IP-10 (R\&D Systems Inc., Minneapolis, MN, USA).

\section{Analysis of $m R N A$ expression}

The general quality of RNA was verified on agarose gel. An amount of $0.5 \mu \mathrm{g}$ RNA was reverse transcribed into cDNA with the Invitrogen 'SuperScript III First Strand Synthesis System for RT-PCR' kit. The primers were designed with Primer Express software v2.0 (Applied Biosystems, Foster City, CA, USA) and tested with Amplify software (Amplify version 3.0, University of Wisconsin, WI, USA). Primers sequences and amplicon sizes are described in Table 1.

Messenger RNA expression was determined using SYBR green technology (qPCR MasterMix Plus for SYBR green I, Eurogentec, Seraing, Belgium) on an AB Prism 7700 Sequence Detector (Applied Biosystems). The gene coding for TATA Box-binding protein was used as housekeeping gene as its expression was unmodified by the experimental conditions. All quantifications were achieved with the comparative $\Delta \Delta C_{\mathrm{t}}$ method and normalized to the endogenous control as described by the manufacturer.

\section{Analysis of GADD153 protein expression}

Fifty micrograms of islet protein was loaded on a $15 \%$ SDSPAGE gel under non-reducing conditions. After separation, proteins were transferred to nitrocellulose membranes, washed and incubated with rabbit anti-GADD153 antibody
Table 1 Primer sequences and amplicon length of genes studied in real-time RT-PCR

Primers sequences: $5^{\prime}-3^{\prime}$

Amplicon

length $(b p)$

\begin{tabular}{|c|c|c|}
\hline \multicolumn{3}{|l|}{ Gene } \\
\hline \multirow[t]{2}{*}{ TBP } & F: АТССТТСАССААТGАСТССТАТG & $18 \varepsilon$ \\
\hline & R: GATGACTGCAGCAAACCGCTT & \\
\hline \multirow[t]{2}{*}{ iNOS } & F: CCTTCAGGTATGCGGTATTTGG & 67 \\
\hline & R: TCATGAGCAAAGGCACAGAACT & \\
\hline \multirow{2}{*}{ Fas } & F: GTGTCAGCCTGGTGAACGAAA & 152 \\
\hline & R: ACCACACATCCGCТTCCAA & \\
\hline \multirow[t]{2}{*}{$\mathrm{BiP}$} & F:GAAAGAAGGTCACCCATGCAGTT & 87 \\
\hline & R: CAATAGTGCCAGCATCCTTGGTT & \\
\hline \multirow[t]{2}{*}{ SERCA2b } & F: GCAACGATCTGTGCTCTGTGTA & 80 \\
\hline & R: CCCTTCGCСТCATTGTAATCCA & \\
\hline \multirow[t]{2}{*}{ GADD153 } & F: AGGAGAGAGAAACCGGTCCAAT & 58 \\
\hline & R: AAGGCGAAAGGCAGAGACTCA & \\
\hline \multirow[t]{2}{*}{ MnSOD } & F: AGCAAGGTCGCTTACAGATTGC & 74 \\
\hline & R: CAGTGGAATAAGGCCTGTGGTT & \\
\hline \multirow[t]{2}{*}{ PRDX3 } & F: TTCTCATGCCAAAAGAGAGCC & 106 \\
\hline & R: ACAAAGCCCATGGAGCAGTAC & \\
\hline \multirow[t]{2}{*}{ PRDX5 } & F: GAAAGGAGCAGGTTGGGAGTGT & 9 \\
\hline & R: CCCAGGGACTCCAAACAAAA & \\
\hline \multirow[t]{2}{*}{ ATPase6 } & F: TCGCTTCGCTTTGTACTCTCTT & 122 \\
\hline & R: GGTCAGCAGTCTCTGTGCATTT & \\
\hline
\end{tabular}

complexes $(6.0 \mathrm{mg} / \mathrm{l}$, Sigma). Western blot detection was achieved using the lightning chemiluminescence plus (Perkin Elmer LAS, Inc., Boston, MA, USA).

\section{Statistical analysis}

The statistical significance of variations was evaluated with GraphPad Prism 4 (GraphPad software Inc., San Diego, CA, USA). The comparisons between groups were carried out by one-way ANOVA followed by Newman-Keuls post-tests. The results were reported as means \pm s.E.M. Significance was assumed if $P<0 \cdot 05$.

\section{Results}

Early protein restriction increased apoptotic rate and $\mathrm{NO}^{\circ}$ production in the adult islets, which was prevented by maternal taurine supplementation

In the absence of cytokines, the apoptotic rate was threefold higher in $\mathrm{R}$ islets compared with $\mathrm{C}$ islets (Fig. 1A). Inducible NOS mRNA trended to increase, although the difference did not reach the significance level (Fig. 1B), whereas NO* production was markedly enhanced in $\mathrm{R}$ compared with $\mathrm{C}$ group (Fig. 1C). Taurine given to low-protein mothers (RT group) significantly reduced apoptosis (Fig. 1A) and $\mathrm{NO}^{\circ}$ secretion compared with $\mathrm{R}$ group (Fig. 1C).

Islets from different groups were also cultured with a mixture of IL1B, IFNG and TNF. As shown on the micrographs (Fig. 1A), the number of TUNEL-positive nuclei increased after $24-\mathrm{h}$ incubation with cytokines. Again, 
A

$\mathrm{R}$ islets had a significantly higher apoptotic rate and secreted a higher amount of $\mathrm{NO}^{*}$ compared with $\mathrm{C}$ islets. Taurine decreased both apoptotic rate and $\mathrm{NO}^{*}$ production in $\mathrm{RT}$ islets so that statistical difference was no more observed compared to $\mathrm{C}$ islets (Fig. 1A and C). However, when taurine was administered to $\mathrm{C}$ mothers, apoptotic rate (Fig. 1A), iNOS mRNA (Fig. 1B) and $\mathrm{NO}^{\bullet}$ secretion (Fig. 1C) were enhanced compared with the islets of $\mathrm{C}$ rats not supplemented with the amino acid.

Maternal low-protein diet did not modify Fas $m R N A$ expression or the production of MCP-1 and IP-10 secretion by the islets of the adult progeny

Since Fas-mediated signalling pathway is an important contributor to T-cell mediated $\beta$-cell toxicity in type- 1 diabetes (Loweth et al. 1998, Amrani et al. 2000, Augstein et al. 2003), we also measured the expression of the mRNA coding for the receptor in the islets of the four groups (Fig. 2). Cytokines increased Fas mRNA expression tenfold but there was no effect of maternal diet or early taurine supplementation, either in the absence or presence of cytokines.

MCP-1 and interferon- $\gamma$ inducible protein-10 (IP-10) secretion were measured to assess whether maternal malnutrition would influence the expression of molecules that are known to lead to the establishment of a pro-inflammatory environment in the islets. Indeed, both MCP-1 and IP-10 were found in higher concentration in type-1 diabetes patients (Nicoletti et al. 2002, Cipollone et al. 2005), where they participate in the recruitment and activation of lymphocytes and macrophages implicated in insulitis (Atkinson \& Wilson 2002). Under basal conditions (no cytokines), the secretion of MCP-1 and IP-10 did not reach the detection limit of commercial ELISAs $(11 \cdot 7 \mathrm{pg} / \mathrm{ml}$ and $31 \cdot 2 \mathrm{pg} / \mathrm{ml}$ for MCP-1 and IP-10 respectively). Cytokines increased the production of MCP-1 to $0.5 \mathrm{pg} /$ islet/24 h and IP-10 to $1 \mathrm{pg} /$ islet/ $24 \mathrm{~h}$. Neither the maternal diet, nor the taurine supplementation affected MCP-1 and IP-10 secretion (not shown).

\section{Early malnutrition induced GADD153 $\mathrm{mRN} A$ and protein expression but not BiP and SERCA2b $m R N A$ s in the islets at adult age}

Since endoplasmic reticulum stress is implicated in $\beta$-cell apoptosis (Araki et al. 2003), we studied several key components of the UPR. Without cytokines, maternal low-protein diet did not significantly modify BiP mRNA, or SERCA2b mRNA but lead to a significantly enhanced expression of GADD153 mRNA in the adult islet of the progeny compared with $\mathrm{C}$ islets. Taurine prevented the increased GADD153 mRNA in RT islets but had no effect on BiP or SERCA2b mRNA (Fig. 3A).

After $24 \mathrm{~h}$ of cytokines incubation, BiP mRNA expression was equivalent to that measured in basal conditions but the mRNA levels of SERCA2b were two- to three-fold reduced. After exposure to cytokines, GADD153 mRNA was doubled in each group. The difference of expression between $\mathrm{R}$ and $\mathrm{C}$ lost significance although the trend persisted.

A western blot analysis was then performed to assess whether the effects of maternal low-protein diet and of early taurine supplementation on GADD153 expression were confirmed at the protein level. As shown in Fig. 3B, the band corresponding to the GADD153 protein was clearly observed in the $\mathrm{R}$ group, whereas the protein was absent from $\mathrm{C}$ and RT islets.

\section{Early low-protein diet increased PRDX $5 \mathrm{mRN} A$ expression and reduced ATPase $6 \mathrm{mRN} A$ level}

We then studied the effect of maternal malnutrition and early taurine supplementation on the mitochondrial antioxidant defence capacity in the adult islets. We focused on MnSOD as well as peroxiredoxin (PRDX) 3 and 5, two hydrogen peroxide scavengers expressed in $\beta$-cells (Romanus et al. 2007). Neither PRDX3 nor MnSOD mRNA were found to be modified by early low-protein diet in the adult islets incubated in the absence of cytokines (Fig. 4). Only PRDX5 mRNA was significantly overexpressed in the $\mathrm{R}$ group compared with the $\mathrm{C}$ group. After early taurine supplementation PRDX5 expression was slightly reduced in the RT islets, so that there was no difference when the expression was compared with controls. On the other hand, early taurine supplementation led to an enhanced transcription of PRDX5 in the CT islets compared with $\mathrm{C}$ islets. When cytokines were added to culture medium, the MnSOD mRNA was largely stimulated in each group of islets and particularly in the RT islets where the mRNA expression was significantly different compared with $\mathrm{R}$ islets.

Finally, the expression of ATPase6 mRNA was investigated. The choice of this gene was motivated by the following. First of all, ATPase 6 is encoded by the mitochondrial genome. Secondly, the gene codes for subunit 6 of the ATP

Figure 1 Maternal low-protein diet increased apoptotic rate, iNOS mRNA expression and nitric oxide produced by islets of adult progeny, whereas early taurine supplementation had a protective role on these parameters. Rats from control (C), recovery (R), control + taurine (CT) and recovery + taurine (RT) groups were cultured for $48 \mathrm{~h}$ before being incubated with or without IL1B, IFNG and TNF for $24 \mathrm{~h}$.

(A) Representative micrograph of a non-treated islet (left panel) and cytokines incubated islets (right panel). Apoptotic nuclei were labelled using a fluorescein coupled probe (green) and total nuclei with ethidium bromide (red). Scale bar represents $50 \mu \mathrm{m}$. The number of fluorescein-positive nuclei was reported to the number of ethidium bromide positive cells and expressed as a percentage of apoptotic cells per islet. (B) The cDNA samples were amplified in parallel with TBP specific primers and results were expressed relative to controls. Six to nine samples were used per group. (C) The NO• production was quantified with 2, 3-diaminonaphtalene method. Data represent nitrite measured in the culture media by $17-19$ different pools of 70 islets per group after $24-\mathrm{h}$ incubation. Results are means \pm s.E.M. ${ }^{*} P<0 \cdot 05$, ${ }^{* * *} P<0 \cdot 001$ vs $C ;{ }^{+} P<0 \cdot 05,{ }^{++} P<0 \cdot 01$ vs R. 

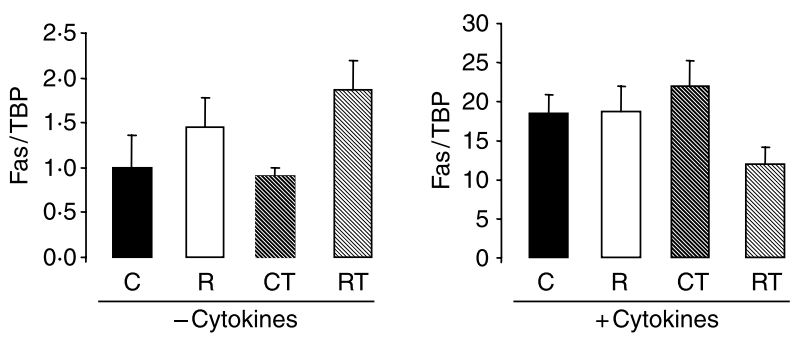

Figure 2 Maternal low-protein diet and early taurine supplementation did not influence the expression of Fas receptor mRNA in the adult islets. Rats from control $(\mathrm{C})$, recovery $(\mathrm{R})$, control+ taurine $(C T)$ and recovery + taurine (RT) groups were cultured for $48 \mathrm{~h}$ before being incubated with or without IL1B, IFNG and TNF for $24 \mathrm{~h}$. The cDNA samples were amplified in parallel with TBP specific primers and results are expressed relative to controls. Seven to eight samples per group were used under basal conditions, with five to six samples per group for cytokines incubation.

pump and by this way intervenes in ATP production (Lee et al. 2003). Without cytokines, ATPase6 mRNA was dramatically reduced in adult islets of $\mathrm{R}$ group compared with $\mathrm{C}$ group but was completely normalized by early taurine supplementation (Fig. 4). Cytokines led to a fourfold reduction of ATPase6 mRNA except in $\mathrm{R}$ group where mRNA expression was already very low. In these conditions, CT islets expressed more ATPase 6 mRNA than $\mathrm{C}$ islets.

\section{Discussion}

Since the purpose of this study was to discover the pathways leading to higher vulnerability of islets from early proteinrestricted rats and how taurine supplementation protects from apoptosis, we analyzed the expression of factors known to intervene in islet-cell death and related these results to the apoptotic rate.

Already in the absence of cytokines, the higher apoptotic rate in $\mathrm{R}$ islets correlated with an increased production of $\mathrm{NO}^{\circ}$. Such increased NO production could be related to the increased iNOS expression, but other NOS may participate to this increased $\mathrm{NO}$ production in $\mathrm{R}$ islets. Adult islets contain endothelial cells that may produce NO by eNOS activity and some endothelial cells may still be present in isolated islets after 3 days of culture. Pancreatic $\beta$-cells also express neuronal constitutive NOS (Lajoix et al. 2001, Mosen et al. 2008) and neuronal NOS-derived NO has been involved in the glucose-mediated insulin release (Lajoix et al. 2001, Henningsson et al. 2002). In basal conditions (without cytokines), it is not possible to identify the participation of each of the NOS activities in the increased production of NO in the $\mathrm{R}$ islets but, the important finding of this work is that more NO is produced in basal conditions by adult islets from offspring of mothers fed a low-protein diet during gestation and lactation which may reduce the viability of $\beta$-cells.

Increasing evidence suggests that $\mathrm{NO}^{\circ}$-induced $\beta$-cell apoptosis is partly mediated by the ER stress pathway


B

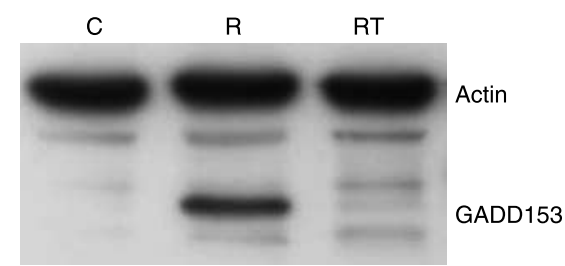

Figure 3 Effect of maternal low-protein diet and early taurine supplementation on BiP and SERCA2b mRNA as well as on GADD153 mRNAs and protein expression in the islets of the adult progeny. Rats from control $(C)$, recovery $(R)$, control + taurine $(C T)$ and recovery + taurine (RT) groups were cultured for $48 \mathrm{~h}$ before being incubated with or without IL1B, IFNG and TNF for $24 \mathrm{~h}$. (A) The cDNA samples were amplified in parallel with TBP specific primers and results are expressed relative to controls. Values are means \pm S.E.M. of five to eight samples per group. ${ }^{*} P<0 \cdot 05$ vs $C$ and ${ }^{+} P<0.05$ vs R. (B) Fifty microgram of islets protein were immunoblotted using an anti-GADD153 antibody and an anti- $\beta$ actin antibody as housekeeping protein.

(Oyadomari et al. 2001). To evaluate the effect of maternal protein-restriction on ER homeostasis in adult islets, we first quantified the level of mRNA coding for BiP, an ER chaperone that also acts as a regulator of the ER signal 

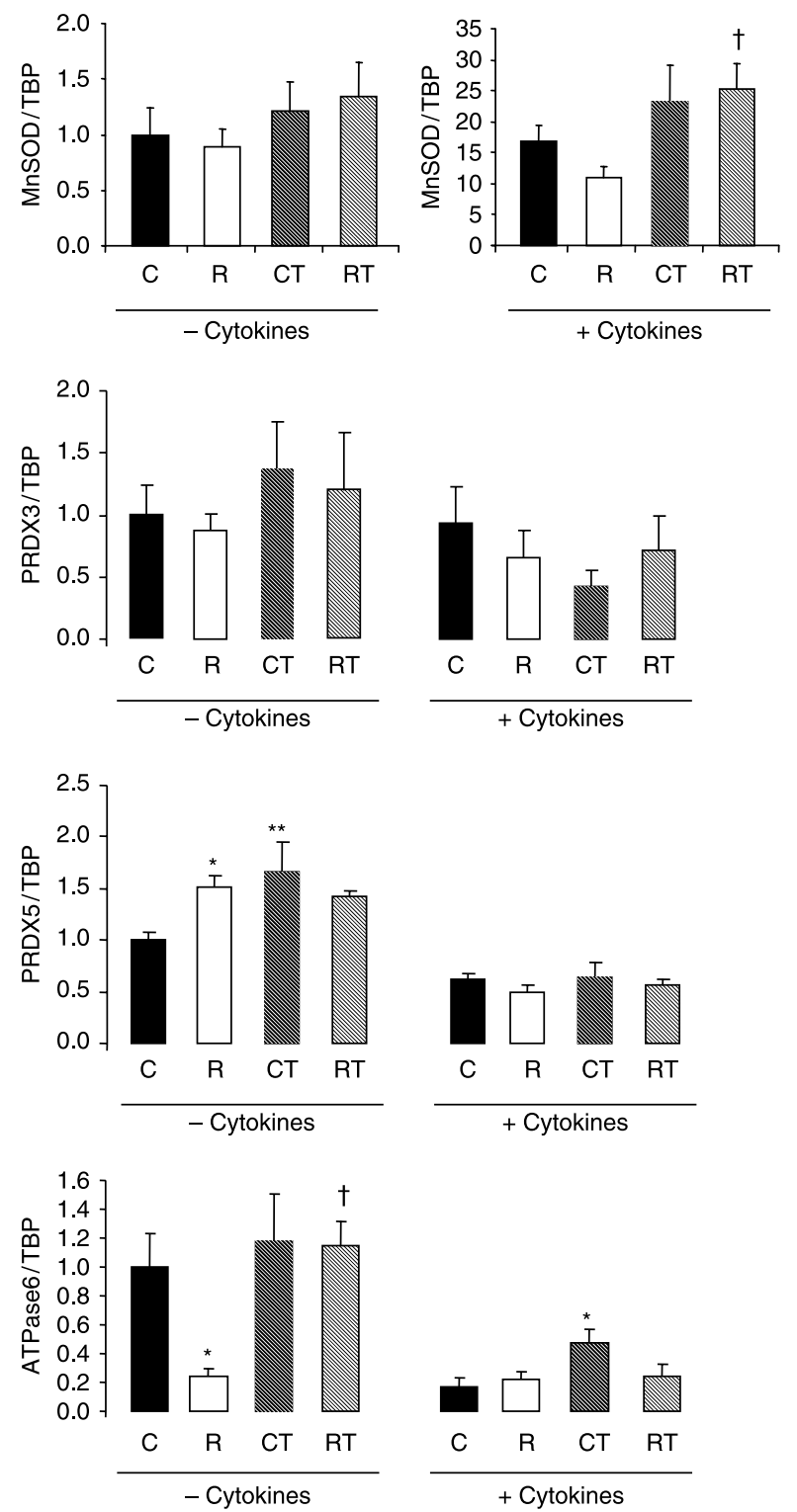

Figure 4 Expression of antioxidant enzymes MnSOD, PRDX3, PRDX5 mRNAs and ATPase 6 mRNA in islets of adult progeny. Rats from control $(C)$, recovery $(R)$, control + taurine $(C T)$ and recovery + taurine (RT) groups were cultured for $48 \mathrm{~h}$ before being incubated or not with IL1B, IFNG and TNF for $24 \mathrm{~h}$. The cDNA samples were amplified in parallel with TBP specific primers and results were expressed relative to controls. Results are means \pm S.E.M. of five to nine samples per group. ${ }^{*} P<0.05$ vs $C,{ }^{* *} P<0.01$ vs $C$ and ${ }^{\dagger} P<0.05$ vs $R$.

transduction pathway (Bertolotti et al. 2000). In unstimulated conditions, $\mathrm{R}$ islets exhibited a trend to increase BiP mRNA compared with $\mathrm{C}$ islets. To better characterize ER stress in islets of early low protein fed rats, we studied the expression of SERCA2b mRNA. This pump reloads $\mathrm{Ca}^{2+}$ into the ER lumen and avoids calcium accumulation in the cytosol during ER stress and subsequent metabolism perturbation. Maternal low-protein diet had no effect on the expression of this gene.
However, despite the absence of mRNA modulation, a defect at the level of SERCA2b activity cannot be excluded in R islets since we showed that these islets produce large amounts of $\mathrm{NO}^{*}$ that was shown to inhibit SERCA activity by modification of cysteine residues of the $\mathrm{Ca}^{2+}$ pump (Viner et al. 1999). GADD153 overexpression is involved in a variety of stress response pathways including prolonged ER stress (Oyadomari \& Mori 2004). The mechanisms leading to GADD153-induced cell death remain only partly understood, although it has been shown that GADD153 decreases Bcl-2 level and depletes cellular glutathione content (McCullough et al. 2001). Furthermore, GADD153 upregulates ER oxidase ERO1 $\alpha$ that perturbs redox state and induces oxidative stress (Marciniak et al. 2004). We found that the maternal low-protein diet led to an overexpression of GADD153 mRNA and protein in islets of the progeny incubated in basal conditions. This could partly explain the increased apoptotic rate observed in the $\mathrm{R}$ islets. It has been recently shown that the modulation of GADD153 expression by $\beta$-cells exposed to cytokines was dependent on the $\mathrm{NO}^{*}$ production since the addition of iNOS inhibitor to culture medium containing cytokines normalized the expression of that gene (Kutlu et al. 2003). Moreover, $\mathrm{NO}^{*}$ is susceptible to react with superoxide anion $\left(\mathrm{O}_{2}^{-}\right)$within the mitochondria in order to generate peroxinitrite $\left(\mathrm{ONOO}^{-}\right.$; Ghafourifar et al. 1999). This powerful oxidizing agent has been shown to be a strong inducer of GADD153. The mechanism would involve mitogen-activated protein kinases (MAPK) rather than ER signalling pathway. Indeed, the p38 kinase was shown to regulate GADD153 by protein phosphorylation (Wang \& Ron 1996) but also by intervening on mRNA transcription (Oh-Hashi et al. 2001). Both GADD153 mRNA and protein expression were induced in $\mathrm{R}$ group.

The function of ER is intimately connected with that of mitochondria. Mitochondrial dysfunction resulting from mitochondrial DNA mutations elicits GADD153 upregulation (Fujita et al. 2007). Mitochondrial DNA is highly sensitive to $\mathrm{NO}^{\circ} / \mathrm{ONOO}^{-}$attack (Wilson et al. 1997) probably because of the lack of histone protection and the ineffective DNA repair system (Wallace 1994). Recently, Simmons et al. (2005) demonstrated that adult islets from rats with intrauterine growth retardation produced a higher level of ROS, leading to the accumulation of mitochondrial point mutations associated with decreased expression of mitochondrial encoded genes. Based on these observations, we assessed the effect of early malnutrition on the expression of the mitochondrial gene ATPase 6 in islets of adult progeny. In non-stimulating conditions, ATPase6 mRNA expression was strongly downregulated in $\mathrm{R}$ islets compared with $\mathrm{C}$ islets. We did not perform ATP assay in the present study but we know that ATP production is compromised in the progeny of mothers fed a low-protein diet. Indeed, the consequences of the maternal low-protein diet during gestation on the mitochondrial function in islet at adulthood is currently being investigated in our laboratory and we observed that ATP synthesis was blunted after glucose stimulation in the 
3-month-old female progeny fed a low-protein diet during gestation. This correlated with $50 \%$ reduction of the ATPase 6 mRNA expression in these female islets (Theys et al. 2008). In addition, at foetal age, we already showed that low-protein islets were unable to enhance ATP production in response to glucose (Reusens et al. 2008). Moreover, the insulin secretion by these foetal islets was reduced after stimulation with secretagogues compared with control islets (Cherif et al. 1998).

Peroxinitrite formation can be avoided by dismutation of $\mathrm{O}_{2}^{-}$by manganese superoxide dismutase (MnSOD). The expression of this enzyme was analyzed in the islets but no significant difference was found between rats that were earlier fed either a low- or a normal- protein diet. Antioxidant defence state is very low in islets compared with liver tissue, especially the level of peroxide scavengers such as glutathione peroxidase (GPX) and catalase (Tiedge et al. 1997). The role of the peroxidase PRDX has particularly drawn attention in recent years. The family is composed of six members coded by different genes but only isoforms -3 and -5 were found within mitochondria (Wood et al. 2003). Our results showed that PRDX3 mRNA was unmodified by maternal diet but R islets overexpressed PRDX5 mRNA in basal conditions compared with controls. PRDX3 and PRDX5 differ by at least two important characteristics: i) unlike PRDX3, PRDX5 reduces $\mathrm{ONOO}^{-}$with a high rate constant (Dubuisson et al. 2004) ii) PRDX5 localization is not restricted to mitochondria since the protein is also detected in cytosol and peroxisomes (Knoops et al. 1999, Seo et al. 2000). These data suggest that the increased expression level of PRDX5 in R islets might be related to a high $\mathrm{ONOO}^{-}$ production.

In our study, cytokines increased apoptosis in each group of islets by enhancing $\mathrm{NO}^{*}$ production and inducing Fas as well as GADD153 mRNA. Moreover, $24 \mathrm{~h}$ cytokines incubation activated the release of chemokines MCP-1 and IP-10 and reduced ER stress protector SERCA2b, antioxidant enzyme PRDX5 and ATPase6 mRNA. These results are in agreement with others studies (Cardozo et al. 2001a, Darville \& Eizirik 2001, Kutlu et al. 2003). Cytokines modified Fas mRNA but the expression was not affected by maternal diet suggesting that Fas pathway is not involved in the higher sensitivity of $\mathrm{R}$ islets. Interestingly, using iNOS-deficient and Fas-deficient islets, Zumsteg et al. (2000) demonstrated that Fas-induced $\beta$-cell death was independent of $\mathrm{NO}^{*}$ pathway. Also MCP-1 and IP-10, whose expression were unmodified by maternal low-protein diet in our study, were unchanged in MIN6 cells incubated with iNOS inhibitor (Baker et al. 2003).

In contrast to Fas, it is well known that cytokines induce apoptosis in $\beta$-cells by a $\mathrm{NO}^{-}$-dependent pathway due to an increased iNOS mRNA and protein expression. By knocking out the enzyme in the mouse (Liu et al. 2000) and using iNOS inhibitor in the rat (Cardozo et al. 2005) it was shown that iNOS is largely responsible for $\beta$-cell apoptosis in the presence of cytokines (Storling et al. 2005). These data support the hypothesis that $\mathrm{NO}^{*}$ plays a key role in the $\mathrm{R}$ group islet-cell death. As iNOS transcription is regulated in a complex manner by several constitutive and inducible transcription factors including NFKB (Cardozo et al. 2001b), p38 and ERK1/2 MAPK (Larsen et al. 1998), it is likely that any factor that affects these signalling pathways modulate the enzyme expression. Nutrients present in the islets environment could intervene on iNOS expression. Accordingly, Wu \& Meininger (2002) reviewed the effect of dietary factors including glucose, amino acids and free fatty acids on $\mathrm{NO}^{*}$ synthesis and showed that some of them were potent modulators. On the other hand, Yu \& Kone (2004) demonstrated that in vitro methylation of the iNOS promoter silenced the gene in mesangial cells by inhibiting the binding of NFKB to DNA. It is conceivable that maternal diet influenced DNA methylation which perturbs iNOS expression in the islet of the adult progeny.

Foetuses from low-protein fed mothers had decreased plasma taurine concentration compared with foetuses from well-fed mothers but the difference had disappeared at adulthood (Reusens et al. 1995, Merezak et al. 2004). Taurine supplementation to protein-restricted mothers during gestation and lactation restored a normal apoptotic rate in

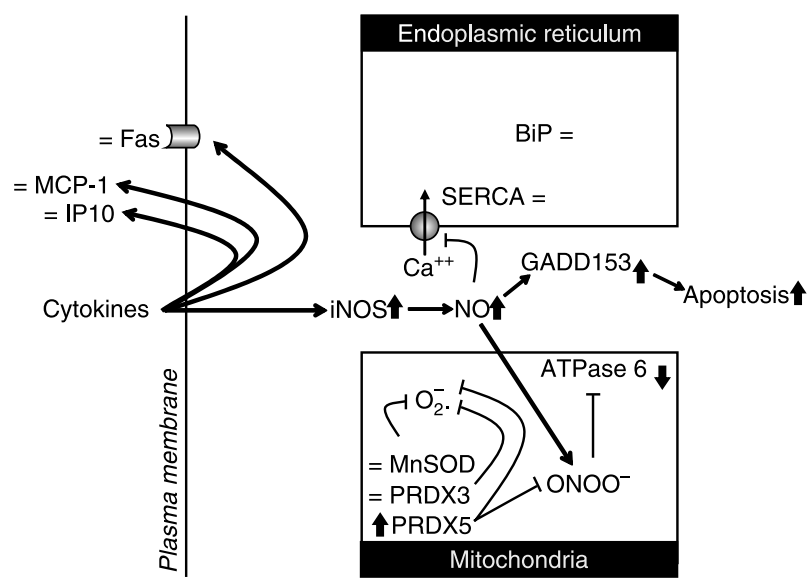

Figure 5 Schematic of the proposed mechanism leading to higher vulnerability in islets of adult progeny fed a low-protein diet during gestation and lactation. Ascending arrows $(\uparrow)$ and descending arrows $(\downarrow)$ correspond to upregulated and downregulated genes respectively in islets of early protein restricted rats $(\mathrm{R})$. Even in the absence of cytokines, inducible nitric oxide synthase (iNOS) mRNA expression and nitric oxide $\left(\mathrm{NO}^{*}\right)$ production were elevated consequently due to maternal malnutrition. The peroxinitrite reductase peroxiredoxin (PRDX5) mRNA level was increased in $\mathrm{R}$ islets cells, presumably due to high peroxinitrite $\left(\mathrm{ONOO}^{-}\right)$ produced by the reaction of $\mathrm{NO}^{*}$ with $\mathrm{O}_{2}^{-}$. Mitochondrial integrity could be affected because ATPase 6 mRNA was markedly reduced in adult islets. This may impair ATP production and contribute to cell death. Another direct cause of the high apoptotic rate observed in $\mathrm{R}$ islets could be the upregulation of growth arrest and DNA damage inducible protein (GADD) 153 which is activated by $\mathrm{NO}^{\circ} / \mathrm{ONOO}^{-}$ or during severe ER stress. As, neither chaperone BiP or SERCA2 pump mRNAs were modified by maternal low-protein diet, ER stress is not obvious in adults islets. 
adult islets cultured in standard conditions and protected these islets after cytokines induction. The long-term protective effect of taurine could be explained by lower $\mathrm{NO}^{*}$ secretion and restored GADD153 and ATPase6 expression in adult islets. During development of the endocrine pancreas it would be possible that taurine acts as a protecting factor for $\beta$-cells. Indeed, we have already shown that taurine given to the protein restricted mother normalized both insulin secretion (Cherif et al. 1998) and ATP production in foetal islets (Reusens et al. 2008). Taurine could have reduced ER stress and modified mitochondrial metabolism since the amino acid was shown to increase calcium storage in ER by stimulating the pumping rate of calcium ATPase pumps (Huxtable 1992) and to modulate the calcium buffering capacity of the mitochondria (El Idrissi 2006). Moreover, taurine-conjugated acid reduced ER stress in ob/ob mice, a model of severe obesity and insulin resistance (Ozcan et al. 2006). On the other hand, we showed that inappropriate taurine supplementation during offspring development is deleterious for the endocrine pancreas of the adults since apoptosis and $\mathrm{NO}^{*}$ production was enhanced compared with well-fed rats not supplemented. It is likely that inadequate taurine levels during development led to the perturbation of islet-cell homeostasis which may modulate cellular differentiation and consequently create a subpopulation of islet cells. These cells may transmit their particular phenotype across the endocrine lineage until adult age.

In summary, we have shown that even in the absence of induction by cytokines, adult islets in the progeny of lowprotein diet fed dams express higher iNOS levels, and consequently secreted large amounts of NO (Fig. 5). Together with $\mathrm{ONOO}^{-}$produced in mitochondria, NO${ }^{*}$ would affect GADD153 expression and lead to triggering apoptosis. Mitochondrial functioning would also be impaired since ATPase6, a mitochondrial encoded gene that intervenes in ATP production was markedly downregulated subsequent to early protein restriction. Taurine supplementation to protein-restricted mothers during gestation and lactation normalized apoptosis levels in the adult islets. We propose that this protection was mediated by decreasing $\mathrm{NO}^{*}$ production leading to restored GADD153 and ATPase6 expression.

This study demonstrates that a maternal low-protein diet programmes a different pattern of gene expression in islets of adult progeny, which render islet cells more susceptible to apoptosis. Nitric oxide appears to play an important role in this increased vulnerability but further experiments are required to elucidate the mechanism that regulate iNOS activation subsequent to maternal low-protein diet and early taurine supplementation.

\section{Declaration of interest}

Authors have no conflict of interest that would prejudice the impartiality of this study.

\section{Funding}

We are grateful to the European Commission (NUTRIX QLK1-200000083, 5th frame programme), to the Parthenon Trust (London, UK) and to the Belgian Fonds National de la Recherche Scientifique (FNRS) for their financial support. K G is a recipient of the "Fonds pour la Recherche dans l'Industrie et l'Agriculture (FRIA)».

\section{References}

Amrani A, Verdaguer J, Thiessen S, Bou S \& Santamaria P 2000 IL-1alpha, IL-1beta, and IFN-gamma mark beta cells for Fas-dependent destruction by diabetogenic CD4(+) T lymphocytes. Journal of Clinical Investigation 105 459-468.

Araki E, Oyadomari S \& Mori M 2003 Endoplasmic reticulum stress and diabetes mellitus. Internal Medicine 42 7-14.

Arredouani A, Guiot Y, Jonas JC, Liu LH, Nenquin M, Pertusa JA, Rahier J, Rolland JF, Shull GE, Stevens M et al. 2002 SERCA3 ablation does not impair insulin secretion but suggests distinct roles of different sarcoendoplasmic reticulum $\mathrm{Ca}(2+)$ pumps for $\mathrm{Ca}(2+)$ homeostasis in pancreatic beta-cells. Diabetes 51 3245-3253.

Atkinson MA \& Wilson SB 2002 Fatal attraction: chemokines and type 1 diabetes. Journal of Clinical Investigation 110 1611-1613.

Augstein P, Wachlin G, Berg S, Bahr J, Salzsieder C, Hehmke B, Heinke P \& Salzsieder E 2003 Surface and intracellular Fas expression associated with cytokine-induced apoptosis in rodent islet and insulinoma cells. Journal of Molecular Endocrinology 30 163-171.

Averous J, Bruhat A, Jousse C, Carraro V, Thiel G \& Fafournoux P 2004 Induction of $\mathrm{CHOP}$ expression by amino acid limitation requires both ATF4 expression and ATF2 phosphorylation. Journal of Biological Chemistry 279 5288-5297.

Baker MS, Chen X, Rotramel A, Nelson J \& Kaufman DB 2003 Proinflammatory cytokines induce NF-kappaB-dependent/NO-independent chemokine gene expression in MIN6 beta cells. Journal of Surgical Research 110 295-303.

Barker DJ, Osmond C, Forsen TJ, Kajantie E \& Eriksson JG 2007 Maternal and social origins of hypertension. Hypertension 50 565-571.

Bertolotti A, Zhang Y, Hendershot LM, Harding HP \& Ron D 2000 Dynamic interaction of $\mathrm{BiP}$ and ER stress transducers in the unfoldedprotein response. Nature Cell Biology 2 326-332.

Bieswal F, Hay SM, McKinnon C, Reusens B, Cuignet M, Rees WD \& Remacle C 2004 Prenatal protein restriction does not affect the proliferation and differentiation of rat preadipocytes. Journal of Nutrition 134 1493-1499.

Boujendar S, Reusens B, Merezak S, Ahn MT, Arany E, Hill D \& Remacle C 2002 Taurine supplementation to a low-protein diet during foetal and early postnatal life restores a normal proliferation and apoptosis of rat pancreatic islets. Diabetologia 45 856-866.

Bruhat A, Jousse C, Wang XZ, Ron D, Ferrara M \& Fafournoux P 1997 Amino acid limitation induces expression of $\mathrm{CHOP}$, a CCAAT/enhancer binding protein-related gene, at both transcriptional and post-transcriptional levels. Journal of Biological Chemistry 272 17588-17593.

Cardozo AK, Kruhoffer M, Leeman R, Orntoft T \& Eizirik DL 2001a Identification of novel cytokine-induced genes in pancreatic beta-cells by high-density oligonucleotide arrays. Diabetes 50 909-920.

Cardozo AK, Heimberg H, Heremans Y, Leeman R, Kutlu B, Kruhoffer M, Orntoft T \& Eizirik DL 2001b A comprehensive analysis of cytokineinduced and nuclear factor-kappa B-dependent genes in primary rat pancreatic beta-cells. Journal of Biological Chemistry 276 48879-48886.

Cardozo AK, Ortis F, Storling J, Feng YM, Rasschaert J, Tonnesen M, Van Eylen F, Mandrup-Poulsen T, Herchuelz A \& Eizirik DL 2005 Cytokines downregulate the sarcoendoplasmic reticulum pump $\mathrm{Ca}^{2+}$ ATPase $2 \mathrm{~b}$ and deplete endoplasmic reticulum $\mathrm{Ca}^{2+}$, leading to induction of endoplasmic reticulum stress in pancreatic beta-cells. Diabetes $\mathbf{5 4} 452-461$. 
Cherif H, Reusens B, Ahn MT, Hoet JJ \& Remacle C 1998 Effect of taurine on the insulin secretion of rat fetal islets from dams fed a low protein diet. Journal of Endocrinology 159 341-348.

Cipollone F, Chiarelli F, Davi G, Ferri C, Desideri G, Fazia M, Iezzi A, Santilli F, Pini B, Cuccurullo C et al. 2005 Enhanced soluble CD40 ligand contributes to endothelial cell dysfunction in vitro and monocyte activation in patients with diabetes mellitus: effect of improved metabolic control. Diabetologia 48 1216-1224.

Dahri S, Snoeck A, Reusens-Billen B, Remacle C \& Hoet JJ 1991 Islet function in offspring of mothers on low-protein diet during gestation. Diabetes 40 115-120.

Darville MI \& Eizirik DL 2001 Cytokine induction of Fas gene expression in insulin-producing cells requires the transcription factors NF-kappaB and C/EBP. Diabetes $\mathbf{5 0} 1741-1748$.

Dubuisson M, Vander SD, Clippe A, Etienne F, Nauser T, Kissner R, Koppenol WH, Rees JF \& Knoops B 2004 Human peroxiredoxin 5 is a peroxynitrite reductase. FEBS Letters 571 161-165.

Duchen MR 2004 Roles of mitochondria in health and disease. Diabetes $\mathbf{5 3}$ S96-S102.

Eizirik DL \& Mandrup-Poulsen T 2001 A choice of death-the signaltransduction of immune-mediated beta-cell apoptosis. Diabetologia $\mathbf{4 4}$ 2115-2133.

Eizirik DL \& Pavlovic D 1997 Is there a role for nitric oxide in beta-cell dysfunction and damage in IDDM? Diabetes/Metabolism Reviews 13 293-307.

Fujita Y, Ito M, Nozawa Y, Yoneda M, Oshida Y \& Tanaka M 2007 $\mathrm{CHOP}(\mathrm{C} / \mathrm{EBP}$ homologous protein) and ASNS (asparagine synthetase) induction in cybrid cells harboring MELAS and NARP mitochondrial DNA mutations. Mitochondrion 7 80-88.

Ghafourifar P, Schenk U, Klein SD \& Richter C 1999 Mitochondrial nitricoxide synthase stimulation causes cytochrome $c$ release from isolated mitochondria. Evidence for intramitochondrial peroxynitrite formation. Journal of Biological Chemistry 274 31185-31188.

Hales CN \& Barker DJ 2001 The thrifty phenotype hypothesis. British Medical Bulletin 60 5-20.

Harding HP \& Ron D 2002 Endoplasmic reticulum stress and the development of diabetes: a review. Diabetes $\mathbf{5 1}$ S455-S461.

Henningsson R, Salehi A \& Lundquist I 2002 Role of nitric oxide synthase isoforms in glucose-stimulated insulin release. American Journal of Physiology. Cell Physiology 283 C296-C304.

Huxtable RJ 1992 Physiological actions of taurine. Physiological Reviews 72 101-163.

El Idrissi A 2006 Taurine increases mitochondrial buffering of calcium: role in neuroprotection. Amino Acids 34 321-328.

Knoops B, Clippe A, Bogard C, Arsalane K, Wattiez R, Hermans C, Duconseille E, Falmagne P \& Bernard A 1999 Cloning and characterization of AOEB166, a novel mammalian antioxidant enzyme of the peroxiredoxin family. Journal of Biological Chemistry 274 30451-30458.

Kozutsumi Y, Segal M, Normington K, Gething MJ \& Sambrook J 1988 The presence of malfolded proteins in the endoplasmic reticulum signals the induction of glucose-regulated proteins. Nature 332 462-464.

Kutlu B, Cardozo AK, Darville MI, Kruhoffer M, Magnusson N, Orntoft T \& Eizirik DL 2003 Discovery of gene networks regulating cytokine-induced dysfunction and apoptosis in insulin-producing INS-1 cells. Diabetes $\mathbf{5 2}$ 2701-2719.

Lajoix AD, Reggio H, Chardès T, Péraldi-Roux S, Tribillac F, Roye M, Dietz S, Broca C, Manteghetti M, Ribes G et al. 2001 A neuronal isoform of nitric oxide synthase expressed in pancreatic beta-cells controls insulin secretion. Diabetes 50 1311-1323.

Larsen CM, Wadt KA, Juhl LF, Andersen HU, Karlsen AE, Su MS, Seedorf K, Shapiro L, Dinarello CA \& Mandrup-Poulsen T 1998 Interleukin-1betainduced rat pancreatic islet nitric oxide synthesis requires both the p38 and extracellular signal-regulated kinase 1/2 mitogen-activated protein kinases. Journal of Biological Chemistry 273 15294-15300.

Lee SH, Lee S, Jun HS, Jeong HJ, Cha WT, Cho YS, Kim JH, Ku SY \& Cha KY 2003 Expression of the mitochondrial ATPase6 gene and Tfam in Down syndrome. Molecular Cell 15 181-185.
Liu D, Pavlovic D, Chen MC, Flodström M, Sandler S \& Eizirik DL 2000 Cytokines induce apoptosis in beta-cells isolated from mice lacking the inducible isoform of nitric oxide synthase (iNOS $-/-$ ). Diabetes 49 $1116-1122$.

Loweth AC, Williams GT, James RF, Scarpello JH \& Morgan NG 1998 Human islets of Langerhans express Fas ligand and undergo apoptosis in response to interleukin-1beta and Fas ligation. Diabetes 47 727-732.

Marciniak SJ, Yun CY, Oyadomari S, Novoa I, Zhang Y, Jungreis R, Nagata K, Harding HP \& Ron D 2004 CHOP induces death by promoting protein synthesis and oxidation in the stressed endoplasmic reticulum. Genes and Development 18 3066-3077.

McCullough KD, Martindale JL, Klotz LO, Aw TY \& Holbrook NJ 2001 Gadd153 sensitizes cells to endoplasmic reticulum stress by down-regulating Bcl2 and perturbing the cellular redox state. Molecular and Cellular Biology 21 1249-1259.

Merezak S, Hardikar AA, Yajnik CS, Remacle C \& Reusens B 2001 Intrauterine low protein diet increases fetal beta-cell sensitivity to NO and IL-1 beta: the protective role of taurine. Journal of Endocrinology $\mathbf{1 7 1}$ 299-308

Merezak S, Reusens B, Renard A, Goosse K, Kalbe L, Ahn MT, TamaritRodriguez J \& Remacle C 2004 Effect of maternal low-protein diet and taurine on the vulnerability of adult Wistar rat islets to cytokines. Diabetologia 47 669-675.

Mosen H, Ostenson CG, Lundquist I, Alm P, Henningsson R, JimenezFeltstrom J, Guenifi A \& Salehi A 2008 Impaired glucose-stimulated insulin secretion in GK rat is associated with abnormalities in islet nitric oxide production. Regulatory Peptides 151 139-146.

Newsholme P, Haber EP, Hirabara SM, Rebelato EL, Procopio J, Morgan D, Oliveira-Emilio HC, Carpinelli AR \& Curi R 2007 Diabetes associated cell stress and dysfunction: role of mitochondrial and non-mitochondrial ROS production and activity. Journal of Physiology 583 9-24.

Nicoletti F, Conget I, Di Mauro M, Di Marco R, Mazzarino MC, Bendtzen K, Messina A \& Gomis R 2002 Serum concentrations of the interferongamma-inducible chemokine IP-10/CXCL10 are augmented in both newly diagnosed type I diabetes mellitus patients and subjects at risk of developing the disease. Diabetologia 45 1107-1110.

Oh-Hashi K, Maruyama W \& Isobe K 2001 Peroxynitrite induces GADD34, 45, and 153 VIA p38 MAPK in human neuroblastoma SH-SY5Y cells. Free Radical Biology and Medicine 30 213-221.

Oyadomari S \& Mori M 2004 Roles of CHOP/GADD153 in endoplasmic reticulum stress. Cell Death and Differentiation 11 381-389.

Oyadomari S, Takeda K, Takiguchi M, Gotoh T, Matsumoto M, Wada I, Akira S, Araki E \& Mori M 2001 Nitric oxide-induced apoptosis in pancreatic beta cells is mediated by the endoplasmic reticulum stress pathway. PNAS 98 10845-10850.

Ozcan U, Yilmaz E, Ozcan L, Furuhashi M, Vaillancourt E, Smith RO, Gorgun CZ \& Hotamisligil GS 2006 Chemical chaperones reduce ER stress and restore glucose homeostasis in a mouse model of type 2 diabetes. Science 313 1137-1140.

Ravelli AC, Bleker OP, Roseboom TJ, van Montfrans GA, Osmond C \& Barker DJ 2005 Cardiovascular disease in survivors of the Dutch famine. Nestlé Nutrition Workshop Series. Paediatric Programme 55 183-191.

Reusens B, Dahri S, Snoeck A, Bennis-Taleb N, Remacle C \& Hoet JJ 1995 Long-term consequences of diabetes and its complications may have a fetal origin: experimental and epidemiological evidence. Diabetes Nestlé Nutrition Workshop Series, vol 35, pp 187-198.

Reusens B, Sparre T, Kalbe L, Bouckenooghe T, Theys N, Kruhoffer M, Orntoft T, Nerup J \& Remacle C 2008 The intrauterine metabolic environment modulates the gene expression pattern in foetal rat islets: prevention by maternal taurine supplementation. Diabetologia 51 836-845.

Romanus P, Bouckenooghe T, Vanderwalle B, Remacle C, Knoops B \& Reusens B 2007 Do peroxiredoxins reduce the vulnerability of insulinsecreting cells to cytokines? Diabetologia 50 P0441.

Schapira AH 2006 Mitochondrial disease. Lancet 368 70-82.

Seo MS, Kang SW, Kim K, Baines IC, Lee TH \& Rhee SG 2000 Identification of a new type of mammalian peroxiredoxin that forms an intramolecular disulfide as a reaction intermediate. Journal of Biological Chemistry 275 20346-20354. 
Simmons RA, Suponitsky-Kroyter I \& Selak MA 2005 Progressive accumulation of mitochondrial DNA mutations and decline in mitochondrial function lead to beta-cell failure. Journal of Biological Chemistry $\mathbf{2 8 0}$ 28785-28791.

Snoeck A, Remacle C, Reusens B \& Hoet JJ 1990 Effect of a low protein diet during pregnancy on the fetal rat endocrine pancreas. Biology of the Neonate 57 107-118.

Storling J, Binzer J, Andersson AK, Zullig RA, Tonnesen M, Lehmann R, Spinas GA, Sandler S, Billestrup N \& Mandrup-Poulsen T 2005 Nitric oxide contributes to cytokine-induced apoptosis in pancreatic beta cells via potentiation of JNK activity and inhibition of Akt. Diabetologia 48 2039-2050.

Sturman JA 1993 Taurine in development. Physiological Reviews 73 119-147.

Theys N, Reusens B \& Remacle C 2008 Early programming of islet antioxidant activities and mitochondrial function by maternal low protein diet. Diabetologia $\mathbf{5 1 ~ S 1 1 4 . ~}$

Tiedge M, Lortz S, Drinkgern J \& Lenzen S 1997 Relation between antioxidant enzyme gene expression and antioxidative defense status of insulin-producing cells. Diabetes 46 1733-1742.

Vanhala M, Vanhala P, Kumpusalo E, Halonen P \& Takala J 1998 Relation between obesity from childhood to adulthood and the metabolic syndrome: population based study. BMJ 317319.

Viner RI, Williams TD \& Schoneich C 1999 Peroxynitrite modification of protein thiols: oxidation, nitrosylation, and S-glutathiolation of functionally important cysteine residue(s) in the sarcoplasmic reticulum Ca-ATPase. Biochemistry 38 12408-12415.
Wallace DC 1994 Mitochondrial DNA sequence variation in human evolution and disease. PNAS 91 8739-8746.

Wang XZ \& Ron D 1996 Stress-induced phosphorylation and activation of the transcription factor CHOP (GADD153) by p38 MAP Kinase. Science 272 1347-1349.

Wilson GL, Patton NJ \& LeDoux SP 1997 Mitochondrial DNA in beta-cells is a sensitive target for damage by nitric oxide. Diabetes 46 1291-1295.

Wood ZA, Schroder E, Robin HJ \& Poole LB 2003 Structure, mechanism and regulation of peroxiredoxins. Trends in Biochemical Sciences 28 32-40.

Wu G \& Meininger CJ 2002 Regulation of nitric oxide synthesis by dietary factors. Annual Review of Nutrition 22 61-86.

Yu Z \& Kone BC 2004 Hypermethylation of the inducible nitric-oxide synthase gene promoter inhibits its transcription. Journal of Biological Chemistry 279 46954-46961.

Zumsteg U, Frigerio S \& Hollander GA 2000 Nitric oxide production and Fas surface expression mediate two independent pathways of cytokine-induced murine beta-cell damage. Diabetes 49 39-47.

Received in final form 3 November 2008

Accepted 23 November 2008

Made available online as an Accepted Preprint 27 November 2008 